Est Ag 46 (2011) 157-168

\title{
Corpse Eaters, Cartoons and the Blasphemy Law ${ }^{1}$
}

\author{
Peter G. PandimakiL*
}

Within the general category of media and religion, one may deal with a variety of topics such as the impact of media on religion, the overwhelming presence, palpable absence or wise ignorance of religion in media, the theoretical grounding of media in particular religious conceptions for example Christian, Jewish, Islamic, etc. This paper dwells on a current topic which has both theoretical and very drastic practical consequences. It is the blasphemy law still in vigor in Pakistan, and has been under media scrutiny for various reasons which worth consideration. However, the topic needs be explained and understood in a larger cultural context which might elucidate the matter more thoroughly.

This brief paper would hence introduce the blasphemy law as a continuation, or better as the sign of a continuous adherence to a pattern of thought endemic to religion, presently evidenced through Islam. The blasphemy law has a ring of the protests against the cartoon controversy started with the Danish publication of satiric images of Muhammad. But it would again be very narrow if the publication of the cartoons and the protests against it are not set against a cultural, religious and social anathema to laugh at or make fun of any religious trait - an issue genially concealed in Umberto Eco's The Name of the Rose. Without elaborating on Eco, this paper sets

\footnotetext{
* ppandimakil@ustpaul.ca

Estudio Agustiniano, Valladolid

Saint Paul University, Ottawa

1 This is a slightly revised version of a paper presented to a work-group on media and religion at St. Paul University, Ottawa, on $11^{\text {th }}$ June, 2011.
} 
out with a concrete incident in Saudi Arabia. It is the story of the corpse eaters.

The essay consists of three parts concentrating on three differentiated cultural contexts: the blasphemy law referring concretely to Pakistan (III), the cartoon controversy involving Europe as well as the Islamic world (II), and the topic of corpse eaters restricted to the immigrant world (I). All these issues point to the fact that media and religion maintain a tensionfilled relationship. Is media manipulating religion? Or does religion consider media as subservient? Why this mutual mistrust or antagonism? What would be hence a framework within which the media might enrich the religious experience: practice and theory? Is there a model of interaction between media and religion founded perhaps on commonalities? Or is it too much to ask for, and one should suffice with notions of orientation enabling mutual enrichment? These and similar considerations may provide a larger scope to reflect on the issues arising between media and religion. This reflection, however, only introduces the topic; it intends to inspire foundational considerations such as a theological perspective specific to a religion or one that goes beyond a single religion's rationale. Should there be a theology of media appropriate to the pragmatic concerns of lived religion? Or should such a theology, if ever possible, be only theoretical?

\section{A drama gone astray?}

Some years ago, around the year 1985, an immigrant worker from India, a Keralite, published a drama criticizing three influential world religions based on an apparently historical incident in Saudi Arabia. It was also reported that during his stay in that country as an expatriate he enacted the drama for the numerous seasonal and established long-time workers from the subcontinent. And he had to leave the country stealthily and promptly abandoning his job, for the Saudi authorities were informed of his anti-religious cultural activity and were intent on arresting him for blasphemy charges. All this was reported only after the author was safe in his homeland, and the drama was acclaimed by a major periodical as a significant literary piece ${ }^{2}$.

2 The dramatic piece is published in Malayalam: Savamteenikal (= Corpse Eaters) was discussed extensively in the Malayalam Weekly, Mathrubhumi in connection with the 
The plot was quite simple: a middle-aged woman of Indian origin was found dead on a street in the capital city (Riyadh) of Saudi Arabia. Called upon to verify the cause of the death and her status, the Police could only come up with the answer that it was of natural causes. The corpse was hence assigned for burial; however, it was necessary to determine her religion in order to administer the proper religious ritual. From the clothes worn by her she could be identified as a Muslim, but the work-permit she carried showed her name to be Hindu. Further investigations brought out that she had almost exclusively Christian friends and moved about only with them. Arguing that she worked in the house of a Muslim and was dressed according to the Islamic custom, the Wahabi religious authorities insisted that she is a Muslim. This appropriation was contested by the representative of the Hindus who argued that she was born as a Hindu and hence carried the name. Friends of hers however were convinced that she became a Christian and frequented Church services whenever possible. Whereas all the three religions wanted to appropriate her, none was prepared to let her be buried without the rituals. As long as her religious identity was proved without doubt, no burial would take place - declared the authorities. And the investigation of the case took a while, letting the corpse be eaten by moths; implicitly the fanatic religious moths.

The drama's critique of religion highlights the plight of the destitute woman, the unconcern shown by all the three religious authorities towards her corpse (it is allowed to deteriorate) and the self-interest even at a time such as the burial ritual. Caught in the laws and niceties of religious perspectives, the body is left alone; it is brought under the final shame of rotting in public. These and similar notions implicit in the drama propose an alternative namely secular humanism which in the latter half of the $20^{\text {th }}$ century was rampant among the immigrant workers. And this was also an ideology promoted by the media. Two comments, however, seem appropriate: first, the drama is placed in a context of religious pluralism, reminding its readers not only of the essentially Indian religious context, but also of the increasingly pluralistic global society 3 . Would this mean that the media has to choose between the alternatives of secular humanism and religion? Or what would be the role of media in enabling

event mentioned. Unfortunately, even after a hard research, it was unable to find a copy of the book, nor of the Mathrubhumi article; all details given hence are from memory.

3 One might even be reminded of Nathan, the Wise (1779) by Gotthold Ephraim Lessing, 1729-1781. 
the public to take an informed stand? ${ }^{4}$ Is the media too sensationalist? Secondly, the media attention given to the drama reminds us of a contemporary phenomenon: critique and self-critique. Characteristic of our democratic society is the legitimacy to critique other perspectives. Would this not imply also the necessity of self-critique, without which critique may become a mockery of itself? What the media is for should not be defined only in terms of what it is against. And this last point shall be better understood in the context of the cartoon controversy.

\section{Cartoons of Muhammad 5}

The immediate context in which the publication of the cartoons need be set is the period from 1989 to 2005 , where the former marks the fatwa pronounced against Salman Rushdie and the latter points to the failed terrorist attack in London. The Danish Daily Jyllands-Posten published the twelve cartoons of Muhammad on 30th Sept. 2005 in order (in their own words) to protest against the complacency with evil, which especially the European politicians and intelligentsia continued to show despite the attacks in New York (Sept. 11, 2001), Madrid (11 March 2004) and the assassination of Theo van Gogh (2nd Nov. 2004) in Amsterdam. This argument has been advanced also by the then Dutch parliamentarian Ayaan Hisri Ali (an immigrant from Somalia) who accused the European liberals of equating Islamophobia with xenophobia, and double standard. Without entering into the details of these issues, let me briefly address how the Spanish media dealt with the controversy. For among the western European nations, Spain alone has been under the Muslim rule for almost eight centuries which did leave irremovable signs all over in society and culture; the country, thus, serves as a contrast to Denmark and other Northern European democracies.

For the Spanish media, represented especially by the dailies El País and $A B C$, the central issue in the cartoon controversy amounts to all what concerns the freedom of expression. Both the publication of the satiric

\footnotetext{
${ }^{4}$ A significant contribution on this issue - secular humanism versus religion - shall be found in Charles Taylor's, The Secular Age (Cambridge, MS: Harvard Uni. Press, 2007), esp. pp. 550-556 \& 690-710.

5 For a detailed discussion of this issue, see my essay: "La ideología popular y la reacción islámica. Un ensayo sobre la cólera contra las caricaturas de Mahoma", Estudio Agustiniano 42 (2007), 61-101.
} 
images as well as the protests against them show unequivocally that freedom of expression is an inalienable right recognized by western democracies. Hence the question that needs be asked is not if it is right to publish the cartoons or is it permitted to protest against the publication, but the issue is: has the freedom of expression any limits? In other words, should one aspire to own up to the right of freedom of expression regardless of whatever consequences it may engender? It is on this specific point that the Spanish and European intelligentsia spoke out through the media. Juan Vernet, a world recognized Spanish Islamic scholar, warns that the exercise of the freedom of expression need respect the other. Tariq Ramadan, a Swiss Muslim and scholar, was of the opinion that the publication of the cartoons was a stupid way of establishing one's right of expression. Conceding the stupidity of the act, Mario Vargas Llosa, the future Nobel laureate and resident of Spain, observed that the silence of the European left only indicates their interest in political correctness, and thereby ignores all of its religious and socio-political concatenations. For instance, do not the protests against the publication reveal the poor integration of the minorities in the European society? Does not one ignore the issue of icon or image in the religious conception, especially when some Muslims affirm the non-existence of any representation of Muhammad?

Although the Daily El País published a few examples of the images of Muhammad in circulation among the Muslims during the Middle Ages, it did not address the issue of aniconism. It is worthwhile to dwell a moment on this issue. Aniconism may be defined as the voluntary refusal to represent God (or the ultimate reality) in any form for the simple reason that the divine is ineffable. Any image would be only an approximation and often runs the risk of distortion. Hence, God can be comprehended neither rationally nor symbolically. The transcendent immanence or the immanent transcendence of the ultimate reality expressed rationally in terms of incommensurability may adequately be justified by this voluntary practical decision of aniconism. This philosophical-theological argument transcends the simplistic description of Islamic or Judaic aniconism as compliance with legal prohibition. Despite highlighting the right of individual freedom in western democracies, the Spanish media did not dwell on the theological or religious dimensions of aniconism or iconoclasm. It did however elaborate on the implications of the freedom of expression.

What does the freedom of expression consist in? Can the publication of the Cartoons be referred to as a valid expression of freedom? Recog- 
nizing that freedom of expression should not be exercised in a frivolous or irresponsible manner, the mainstream Spanish media affirmed that it is essential for a society of equals. Only if we are able to express our convictions without repression, and recognized as responsible persons, capable of thinking and acting on our own, there exists a citizenry of equals. Alone this enables equality of rights and difference in creeds; the only other option is the solitary monologue of the more powerful. However, the freedom of expression is a negative not a positive liberty; negative, because the right does not impede you expressing in conscience; positive, because the right does not have to be exercised. The freedom of expression is there to critique the power and the powerful, not to abuse the subjugated. In other words, it is to defend, guarantee and promote the human dignity which alone would be able to judge if the exercise of the freedom was valid or not. Here is a pattern of thought by which the media can empower the society. Admittedly, much care has been taken here not to side with the publishers or protesters of the Muhammad cartoons. How does the media fair in dealing with Pakistan's blasphemy law?

\section{The Blasphemy Law}

Attention to Pakistan's blasphemy law was aroused recently by two violent incidents: the assassination of the Federal Minister for Minorities (Shahbaz Bhatti - a Catholic, on $2^{\text {nd }}$ March 2011) and that of the Governor of Punjab (Salman Taseer, by his bodyguard Malik Mumtaz Qadri, on $4^{\text {th }}$ Jan. 2011), both of whom defended the right of the Christians to equal citizenship. At least, this is the way how the assassination and the consequent demonstrations in favor of the murders were presented to the outside world by the global media ${ }^{6}$. It may, however, be best to hold one's judgment for a while and dwell on the context of these incidents.

The context of the Blasphemy Law is large, stretches all the way from independence till today. A brief account needs hence highlight at least the main phases. As has been famously declared by its first Prime Minister in

${ }^{6}$ See, for example: "Pakistan on strike against bill to amend blasphemy law" (Dec. 31, 2010) www.bbc.co.uk./news/world-south-asia-12097687; Saroop Ijaz "Pakistan's law not only threatens people like Asia Bibi, it strengthens radicals and the Taliban", in Los Angels Times, January 05, 2011: http://articles.latimes.com/2011/jan/05/opnion/la-oe-ijaz-blasphemy-20110105/2; Sally Sara, "Crowds rally in support of blasphemy law", in www.abc.net.au (Jan. 10, 2011). 
$1949^{7}$, Pakistan came into being as a separate nation in order to enable the faithful to live according to the tenets of Islam. From its very outset, the country has been conceived as an Islamic state and this constituted the priority in both internal governance and external relations (despite the pronouncements of the Founding Father Jinnah) ${ }^{8}$. Recognition of this legitimate aspiration of the people of Pakistan becomes hence a presupposition in discussing the blasphemy law ${ }^{9}$. However there are political and constitutional issues to be clarified, for the Pakistan of today is not what it was politically or geographically in 1947 when independence was obtained from the British Colonial Regime. With the partition ${ }^{10}$ of the British Raj in 1947, Pakistan was declared a free sovereign state consisting of West and East Pakistan (Bangladesh). The separation of Bangla-desh in 1971 marks one of the first major crises in Pakistan's national identity. In order to understand better the impact this had on the conscience of the nation, the issue needs be addressed at least from the constitutional-political and religious-social perspectives. For they provide the backbone of Pakistan's Blasphemy law.

"[C]onstitutional government in Pakistan has been more sham than substance. Pakistan has had five constitutions in its brief history: one inherited at independence (...), and four indigenous creations, in 1956, 1962,1972 , and 1973. Pakistan has also been governed at times without the benefit of a written constitution (...), under a suspended constitution (...), and under a "modified" though "restored" constitution (...), the latter of

7 "Pakistan was founded," Prime Minister Liaquat 'Ali Khan told the Constituent Assembly of Pakistan in March, 1949, "because the Muslims of this sub-Continent wanted to build up their lives in accordance with the teachings and traditions of Islam." Constituent Assembly of Pakistan Debates, Vol. V, no. 1, March 7,1949, p. 2. Quoted in: Freeland Abbott, Islam and Pakistan (Ithaca, N. Y.: Cornell Uni. Press, 1968), p. 183.

${ }^{8} \mathrm{Mr}$. Mohammed Ali Jinnah, had categorically made it clear that the country will not be a theocratic state. In his presidential address to the first Constituent Assembly of Pakistan at Karachi, on September 11, 1947, he said, "We are starting with this fundamental principle that we all are citizens and equal citizens of one state. You may belong to any religion or caste or creed that has nothing to do with the business of the state." For a detailed discussion of the formation of Pakistan, see: Ishtiaq Ahmed, The Concept of an Islamic State (New York: St. Martin's Press, 1987).

${ }^{9}$ For a good discussion on the role of Islam in shaping Pakistan's politics, see: Rafiq Dossani \& Henry S. Rowen (eds.), Prospects for Peace in South Asia (Stanford, CA: Stanford Uni. Press, 2005), esp. pp. 19-108.

10 On the issue of partition, see (for a different perspective): P. Pandimakil, "La India: sesenta años de independencia (1947-2007). Logros y desafíos" in: Estudio Agustiniano 45 (2010) 251-278, esp., pp. 252ff. 
which was wholly altered by the passage of the Thirteenth Amendment (1997-99). Between 1999 and November 2002 the state was governed under a "Provisional Constitution Order," from November 2002 to January 2004 under a "Legal Framework Order," and since then under a constitution which has been wholly revised by the operation of the Seven-teenth Amendment."11 Although another amendment, the Eighteenth, was introduced and the revised constitution has been published in $2010^{12}$, the constitutional issue has not yet been resolved ${ }^{13}$, and it constitutes one of the big challenges facing the current government of Pakistan. However, for the purpose of explaining the impact of the Blasphemy Law it suffices to highlight the military rule ending in 2009 with General Parvez Musharaff as president. The Eighteenth amendment shall be discussed in a different section below.

After having analyzed the development of the various constitutions and the military rule constituting the greater part of Pakistan's post-independent period, Ch. Kennedy draws the following conclusion: "Pakistan's failure to develop a stable constitutional system is the fault of both Pakistan's military and civilian leadership ... Clearly, a constitutional stability can only be achieved if there is an accommodation between the interests of the two sectors of actors ... what is needed are untidy constitutional accommodations, accommodations in which neither the military nor the political parties "wins" or "loses," but in which the interests of both are partially accommodated." 14 Although the two main actors are here correctly indicated, the role that Islam has been playing in it needs be highlighted. If it is correct that all the "conflicts Pakistan has been engaged in Afghanistan, Kashmir, and also domestically ... are all animated by the fundamental relationship between Islamic extremism and Pakistan's national interest,"15 it is evident that Islam shapes the nation's politics. In fact, this is the convincing argument developed by V. Nasr'16.

11 Charles H. Kennedy, "Constitutional and Political Change in Pakistan: The MilitaryGovernance Paradigm" in: R. Dossani \& H. Rowen (eds.), Prospects for Peace in South Asia, p. 37.

12 The complete text is available at: www.infogov.pak/

13 For the current situation, see: http:/www.cfr.org/pakistan/pakistans-constitution/p15657

14 Charles H. Kennedy, "Constitutional and Political Change in Pakistan: The Military-Governance Paradigm" in: R. Dossani \& H. Rowen (eds.), Prospects for Peace in South Asia, pp. 72-73.

15 Vali Nasr, "Islamic Extremism and Regional Conflict in South Asia" in: R:Dossani \& H. Rowen (eds.), Prospects for Peace in South Asia, p. 19.

16 Ibid, pp. 19-36. 
Since the separation of Bangladesh in 1971, Pakistan's identity was more and more defined in terms of Islam, and an ongoing reformation began in unison with Middle Eastern trends. Following the Wahabi conservative interpretation of the Islamic faith and practice ${ }^{17}$, Pakistan also adopted a rigorous implementation of the Shari'ah Law, despite being a majority moderate (predominately Hanafi) Sunni religious society. This means that the original religious intention is still much alive, but is interpreted more and more in a narrow sense which might reflect the socio-political context in which the country finds itself: covert collaboration with the US, overt enmity with India over the issue of Kashmir and aspirations of regional influence and power (signaled through the development of nuclear bomb and collaboration with Taliban).

How shall we hence understand the blasphemy law? The straight forward candid answer is: it embodies all what Pakistan aspires to be - an exemplary Islamic nation, prosperous, powerful, independent in all levels and capable of managing the minorities. In other words, understanding the blasphemy law as discriminatory would not sufficiently explain its significance for the citizenry, nor would its reform be envisioned. The multiple ways in which the law impacts the Pakistani society may be described in terms of the various stages of its development. I shall be mentioning only the main phases and start with the last.

"The Blasphemy Law was introduced in the Pakistan Penal Code as Section 295-C in 1986. Under this Section, any person guilty of defiling the name of [the] Holy Prophet Muhammad (PBUH) was made liable to suffer life imprisonment or death. Later, in 1991, the alternative of life imprisonment was removed under the direction of the Federal Shariat Court; accordingly the only penalty applicable now is death." 18 It is this situation that affects all religious minorities including factions of the Islamic believers (for example the Ahmadis). The law and its interpretation follow a strict definition of Islam incorporated in the constitution under article 260 (3) a \& b:

17 On Wahabi ideology and its impact on Islam, see: Khaled Abou El Fadl, "The Ugly Modern and the Modern Ugly: Reclaiming the Beautiful in Islam," in: Omid Safi (ed.), Progressive Muslims (Oxford: Oneworld Publications, 2004), pp. 33-77, esp. 49ff.

18 "Plight of Ahmadi Muslims in Pakistan (1989-1999)," www.thepersecution.org (posted on: $19^{\text {th }}$ Sept. 2002). 
(a) "Muslin" means a person Who believes in the unity and oneness of Almighty Allah, in the absolute and unqualifield finality of the Prophethood of Muhammad (peace be upon him), the last of the prophets, and does not believe in, or recognize as a prophet o religious reformer, any person who claimed or claims to be a prophet, in any sense of the word or of any discription whatsoever, after Muhammad (peace be upon him); and

(b) "non-Muslin" means a person who in not a Muslim and includes a person belonging to the Christian, Hindu, Sikh, Budhist or Parsi community, a person of the Quadiani gropup or the Lahori group (who call themselves 'Ahmadis' or by any other name), or a Bahai, and a person belonging to any of the scheduled castes.

According to the Ahmadiya ${ }^{19}$ movement, between 1989 and 1999, 189 Ahmadis have been charged under this law, although most of the accused had nothing to do with blasphemy. "In most cases, personal vendetta was the prime mover; in many others, mullas gave vent to their religious prejudices, while in some cases authorities found it convenient and expedient to press charges under this Section. It is surprising that on a number of occasions, no trouble was taken even to concoct evidence or state an apparently valid reason while framing the charge in the FIR (First Information Report), as the aim was to urgently hang a Damocles sword over the victim's head. It can be stated without any risk of exaggeration that none of the blasphemy cases against Ahmadis was well founded, valid or credible." The webpage ${ }^{20}$ which presents this testimony narrates some concrete cases to validate the above argument. Reasons for being accused of blasphemy are flimsy: social issues, non-observance of strict religious rules (postures), unauthorized translation of Qur'an, and even biographies praising one's own mother can serve as grounds of accusation. This

${ }^{19}$ In every country but Pakistan, they are legally identified as Muslims. In Pakistan they are prohibited by law from self-identifying as Muslims. Ahmadiyya is an Islamic religious movement founded in India near the end of the 19th century (on 23rd March 1889) and was known under the name Ahmadiyya Muslim Jama'at (community). Its founder was Mirza Ghulam Ahmad (1835-1908), who claimed to have fulfilled the eschatological prophecies of various world religions and presented himself as the Islamic reformer (mujaddid) heralding the eschaton and the final triumph of Islam. This would make him the mahdi/messiah awaited by Muslims.

20 "Plight of Ahmadi Muslims in Pakistan (1989-1999)": www.thepersecution.org (posted on: 19th Sept. 2002). 
is a pattern which includes the use of the blasphemy law as a politicalweapon and religious enforcement. It has been denounced by Muslims themselves, and the media does often rightly repeat it.

Together with the Ahmadiya community, Christians are mainly the other targets ${ }^{21}$. The Roman Catholic Bishop of Faizalabad, John Joseph, committed suicide on May 5/6, 1998 in front of the iron gate of the Sessions Court of Sahiwal, which convicted Ayub Masih for blasphemy and sentenced him to death (vide judgment passed) on April 27,1998. The bishop's action was a sign of desperation that no dialogue or rational argument would ever be heard by the radical Muslim groups. Sympathetic demonstrations conducted by the Christians highlighting the self-sacrifice of the bishop were banned by authorities, and counter demonstrations in support of the blasphemy law were organized by Muslims. Further, the death of the bishop was interpreted as a murder committed by another Christian/priest, which version the official media took pains to propagate in Pakistan.

The tenacity with which the Pakistan Islamic authority holds on to the maintenance of the blasphemy law may appall outside observers. Pakistani Muslims not only praised the killer of the Punjab governor but also demonstrated strongly against the Federal governments move (after the assassination of the Federal Minister for Minorities) to consider the abrogation of the blasphemy law. Is the nation divided (as some media reports argue) or why such an obstinate stance behind the seemingly partial legislation? No easy or clear answer seems to be available. However, the gradual steps of Islamization starting with the various constitutions $(1956,1962$ \&1973) and subsequent reforms undertaken during the military rule (1977-1987) especially with the dictatorship of General Zia may provide some light. It was during this period that the Penal Code was amended and the Islamic system of punishments known as Hudood laws 22 were introduced. The blasphemy law is part of this program of the enforcement of the laws ordained by the Holy Quran or Sunnah. The minorities do not and cannot play a part here, for they do not belong to the Islamic world or worldview. But since they occupy a living space in the land of Islam, they also are obliged to conform to the Islamic law. In other

${ }^{21}$ Naeem Shakir, "The Blasphemy Law in Pakistan and its Impact," www.hrsolidarity.net (posted on: 2001-08-21).

22 The Hudood (Hudud) Ordinance was enacted in 1979 as part of the then-military ruler Muhammad Zia-ul-Haq's Islamization and replaced or revised in 2006 by the Women's Protection Bill. 
words, the law of the land is Sharia, everyone of the land is subjected to $\mathrm{it}^{23}$. The blasphemy law is the most adequate means of expressing, shaping and promoting the national unity - an ideal of cohesiveness in a world of chaos. This is hence a nationalist agenda built on religious persuasion ${ }^{24}$. And the issue shall be adequately addressed only from multiple perspectives: cultural, religious, social, economic, international, etc. For the law has come to characterize Pakistan's national identity.

In the above discussion, a crucial issue affecting collective livingtogether was presented in order to show the practical dimension of the legal-religious understanding of blasphemy. Its inner logic and the capacity to influence entire societies have been very well shown by Salman Rushdie's novel The Satanic verses. Although the novel itself has been considered a blasphemy of Islam by Islamic fanatics, it joins with Michel Foucault and Pierre Klossowski in affirming that "our civilization has long been one based not on signs but on simulacra." 25 According to the novel, it is the religious authority (Imam) which turns the sign to simulacrum, and the religious law into a madman's document. Has religion become in the contemporary society a simulacrum not a symbol of the transcendence? And did the media (does the media still) also play an active part in this?

23 This may sound a narrow conception and a misrepresentation of Islamic world view today. However, there exists a perfect parallel to this perspective in India represented by the BJP, and a replica in the medieval Christianity clearly pronounced in the axiomatic expression: cuius regio, eius religio.

24 For Charles Taylor the ideology of Pakistan is defensive nationalism, a point worth consideration in understanding what it shares with India and other nationalist ideologies, as well as how its perspective highlights the perceived threat of annihilation. This analysis confirms the function of blasphemy discussed above as identity contributing factor: "For Jinnah and those around him, the impulse to form Pakistan had a lot to do with the preservation of a modernized (and, in Jinnah's case, rather secularized) Muslim identity against the danger of being overwhelmed in a Hindu state. Their own "call to difference" risked being drowned out, they feared, by India's answer to its own call. But when the Muslim League swept the Muslim areas of India in the elections of 1941, the popular slogan was "Islam in danger!" What was being conjured up here was a threat of a more direct and aggressive kind. The ideology of Pakistan propagated itself as a defensive nationalism.

Of course, since then, in a third phase, the original positive aspiration may have propagated itself downward in Pakistani society. It is not easy to judge the extent to which this is so because defensiveness and threat still seem important mainstays of Pakistani unity." Charles Taylor, "Nationalism and Modernity," in: Dilemmas and Connections: Selected Essays (Cambridge, MS: The Belknap Press, 2011), p. 100.

25 David Lawton, Blasphemy (Philadelphia: University of Pennsylvania Press, 1993). 